\title{
Capital markets and perceptions of sectoral sensitivity to COVID-19
}

\author{
Z.Korzeb ${ }^{1}$, P. Niedziótka ${ }^{2}$, D.A.Pankou ${ }^{3}$ \\ ${ }^{1}$ Bialystok University of Technology, \\ 2, Ojca Stefana Tarasiuka st., Kleosin, 16-001, Poland \\ ${ }^{2}$ Warsaw School of Economics, \\ 162, al. Niepodległości, Warsaw, 02-554, Poland \\ ${ }^{3}$ Belarus State Economic University, \\ 6, Partizanski pr., Minsk, 220070, Belarus
}

For citation: Korzeb Z., Niedziółka P., Pankou D. A. (2021) Capital markets and perceptions of sectoral sensitivity to COVID-19. St Petersburg University Journal of Economic Studies, vol. 37, iss. 3, pp.474-488. https://doi.org/10.21638/spbu05.2021.305

This article analyzes the performance of industry sub-indices during the COVID-19 pandemic, done on the basis of the evolution of rates of return for 247 industry indices from $15 \mathrm{Eu}-$ ropean countries in 2020. Differences between the achieved rates of return on industry and the main stock indices in all examined countries were estimated. Additionally, the volatility of individual sector indices over was calculated. This allows us to draw the following conclusions. Firstly, investors considered tourism and the oil and gas and financial sectors to be among industries most vulnerable to COVID-19. Secondly, the need to transfer business to the Internet and to accelerate digital transformation are prerequisites for investors' decisions to increase the share of technology companies in their portfolios. On the other hand, growing uncertainty is impacting the performance of providers of food and other necessities. Due to administrative constraints put on tourism and passenger transport activities, demand for leisure goods increased rapidly, which translated into results and quotations of the entities responsible for their production. The pandemic crisis, contrary to symptoms observed in Q1 2020 and analysts' expectations, did not adversely affect industrial production. Finally, in general, the behavior of investors in the Russian market was similar to that of investors in other economies. However, for the three sub-sectors, the reaction of investors was different.

Keywords: COVID-19, capital markets, sector risk.

(C) St. Petersburg State University, 2021 


\section{Introduction}

The economy entered 2020 globalized and with relatively high Gross Domestic Product (GDP) growth rate facing risks of trade imbalances, increasing protectionism, and a potential climate crisis. One of the catalysts for globalization was digital transformation [Tsenzharik, Krylova, Steshenko, 2020]. Digitalization, international cooperation, extensive state aid, monetary policy easing, and the relatively good performance of the banking sector [Demirguc-Kunt, Pedraza, Ruiz, 2020] and the stability of the financial system, despite the enormous scale and dynamics of the spread of the coronavirus, helped the global economy suffer no more than moderate losses so far. It should be noted, however, that the pandemic has led to a kind of polarization of the standing of individual industries in the economy. Some have experienced a collapse (e.g. trade in shopping malls, tourism, passenger transport, the financial sector), others have gained from the crisis (e. g. IT, production of necessities, media, manufacturing).

In a pandemic period, a typical, fundamental sector risk analysis is insufficient. This is due to at least two reasons. First, the enormous dynamics and variability of the spread patterns and nature of the pandemic make historical data (obtained with a long delay) unsuitable for predictive purposes. Second, the financial performance of individual industries is distorted by state aid measures. This support, which is subject to a significant increase in public debt, cannot be regarded as a permanent phenomenon. At the same time, sector risk is becoming one of the most important determinants of credit risk. It is therefore important to find a tool to capture the level and volatility of a defined industry's risk and position it against the risks of other sectors in the economy.

In order to prioritize the risks of individual industries, we propose an analysis of the behavior of industry sub-indices during the COVID-19 pandemic. Industry sub-indices reflect and to some extent average the behavior of the share prices that make up these indices. The evolution of sub-indices against major stock indices is a proposal of the assessment of industry risk by stock investors. It is a measure that reacts flexibly and quickly to events that determine the conditions for the functioning of individual industries (lockdown, gradual opening or closing of the economy, changes in consumer preferences, the ability to offer products and services remotely, etc.). The analysis of economic sectors during the pandemic was carried out by studying the rate of return of 247 industry indices from 15 European countries in 2020. We estimated differences between achieved rates of return on industry and the main stock indices in all examined countries. In addition to the rates of return thus obtained, the volatility of the individual sector indices over the analysis period were also calculated.

The remainder of this article is structured as follows. Section 2 reviews the most significant literature. The next describes data and methodology employed in the empirical research. Section 4 presents results that are discussed in Section 5. The last part of the manuscript summarises and presents the main conclusions.

\section{Literature review}

COVID-19 contributed to imbalances in the real economy [Bagchi et al., 2020]. It affected the labor market inter alia in terms of remote work [Coibion, Gorodnichenko, Weber, 2020]. The pandemic crisis also triggered monetary policy changes that consisted 
in lowering interest rates and providing liquidity to the financial sector [Hutchinson, Mee, 2020; Guttmann, Lawson, Rickards, 2020]. The first phase of COVID-19 affected international trade by breaching supply chains [Jean, 2020] as well as shaping environment and climate risks [Espejo et al., 2020]. COVID-19, like other crises, has brought an increase in economic uncertainty, limiting the scale of investment and consumption. S. R. Baker et al. undertook to quantify uncertainty during the pandemic by using stock market volatility, newspaper-based economic uncertainty, and uncertainty in business expectation surveys [Baker et al., 2020]. These authors found that about half of the forecasted contraction of GDP in the United States was caused by uncertainty induced by the pandemic. Also A. A. Salisu et al., using news (plausible variants of words used in Google to capture the pandemic) and macro data trends (inter alia oil, gold and stock prices), designed an index measuring uncertainty due to the COVID-19 pandemic [Salisu et al., 2021]. E. Kohlscheen, B. Mojon and D. Rees found that the scale of negative impact of COVID-19 on the economy depends not only on the spread of the pandemic, the number of infected persons, the duration and range of lockdowns, and applied monetary and fiscal policy instruments, but also on measures applied by other governments [Kohlscheen, Mojon, Rees, 2020]. Every crisis brings a certain loss of GDP. Also there was an initial attempt to assess the potential effects of the disruption. According to F. Boissay and P. Rungcharoenkitkul, global GDP may decline by approx. $4-4.5 \%$, with the advanced economies relatively more likely to suffer [Boissay, Rungcharoenkitkul, 2020]. D. Zhang, M. Hu and Q. Ji showed that the pandemic significantly increased the risk of investing in capital markets [Zhang, $\mathrm{Hu}$, Ji, 2020]. Examining the situation in 12 countries in March 2020, R. Dhall and B. Singh noted that the reaction of investors is linked to the impact of COVID-19 on the country's economy [Dhall, Singh, 2020]. S. C. Gherghina, D. S. Armeanu and C. C. Joldes provided evidence that Romanian 10-year government bonds were more sensitive to COVID-related news than the index of the Bucharest Stock Exchange [Gherghina, Armeanu, Joldes, 2020]. N.J.Gormsen and R.S. J.Koijen analyzed claims to dividends, which were then used to estimate GDP growth expected by investors. The research method used, based on dividend forecasts, allowed determining the extent to which the change in the epidemiological situation affects investors' expectations of GDP growth [Gormsen, Koijen, 2020]. N. Sansa examined the relationship between the number of COVID-19 cases and the evolution of the Shanghai Stock Exchange index [Sansa, 2020]. In contrast, A. Landier and D. Thesmar analyzed the impact of volatility in analysts' forecasts for profits of companies listed on the New York Stock Exchange, the National Association of Securities Dealers Automated Quotations) and the American Stock Exchange on their listings during the pandemic crisis. They found that the extent and nature of the impact of the pandemic on the capital market depended on the characteristics of the economy under analysis [Landier, Thesmar, 2020]. F. Gerding, T. Martin and F. Nagler found that cumulative returns and CAPM-adjusted abnormal corporate returns were higher in economies of relatively lower indebtedness compared to GDP, however in line with COVID-19 evolution abnormal returns decreased more in response to the same infections' increase in countries with high debt/GDP ratios [Gerding, Martin, Nagler, 2020]. Analyzing the influence of COVID-19 on the shares' quotations L. Alfaro et al. and T. A. Hassan et al. proved that issuers with relatively better economic and financial standing lost a smaller part of their value than those with poorer performance [Alfaro et al., 2020; Hassan et al., 2020]. On the other hand, using data from 6000 entities in 56 countries, W. Ding et al. showed that com- 
panies representing less pandemic-sensitive industries and carrying out more sustainable operations had relatively better rates of return and lower volatility [Ding, 2020]. Using Wavelets methodology, M.d. C.Valls Martínez and P. A. Martín Cervantes also demonstrated outstanding resilience of companies characterised by high level corporate social responsibility to COVID-induced turbulences on stock markets [Valls Martínez, Martín Cervantes, 2021]. The results of a study designed by M. Pagano, Ch. Wagner and J.Zechner and based on stock option price fluctuations suggest that companies more resilient to social distancing outperform those with lower resilience to the pandemic [Pagano, Wagner, Zechner, 2020]. In the course of a pandemic it is not insignificant whether companies are involved in achieving the Sustainable Development Goals. R. A. Albuquerque et al. proved that stock prices of companies characterized by relatively high environmental and social scores outperformed those for which the Environmental, Social and Governance issues were not priorities [Albuquerque et al., 2020]. As already mentioned, COVID-19 has had a diverse impact on different sectors of the economy. E. Papadimitriou and Z. CseresGergelyne Blaskó designed a sector risk hierarchy that links sector risk with the industry's resilience to COVID-19 [Papadimitriou, Cseres-Gergelyne Blaskó, 2020]. Ch. Chang, M. McAleer and W.-K. Wong proved that COVID-19 has affected mainly tourism, public health, travelling as well as leisure and hospitality [Chang, McAleer, Wong, 2020]. Analyzing Turkey, Z. H. Orhan and N. Tirman added clothing and textile sectors to the list mentioned above [Orhan, Tirman, 2020]. Using data from Portugal, A. Monteiro et al. noted that while COVID-19 has a clear negative impact on tourism, it contributes to improving air quality [Monteiro et al., 2021]. K. Czech and M. Wielechowski proved that the alternative energy industry was more resistant to COVID-19 than the conventional energy sector [Czech, Wielechowski, 2021]. According to Y. Gamil and A. Alhagar, the most important consequences of COVID-19 for the construction sector included suspension of projects, absenteeism, delays, and costs overruns [Gamil, Alhagar, 2020]. P. Babuna et al. state that insurance companies will incur losses inter alia due to cancellation of travel [Babuna et al., 2020]. An analysis of the channels of impact of COVID-19 on the banking sector was carried out by E. Kulińska-Sadłocha, M. Marcinkowska and J. Szambelańczyk [KulińskaSadłocha, Marcinkowska, Szambelańczyk, 2020], while the determinants of banks' resilience to the pandemic crisis were examined by Z. Korzeb and P. Niedziółka [Korzeb, Niedziółka, 2020] and by Z. Korzeb, P. Niedziółka and A. Silva [Korzeb, Niedziółka, Silva, 2021a]. The same authors also explained the reasons for the differences in the cost of banks' risk during the pandemic [Korzeb, Niedziółka, 2021b]. During the pandemic crisis investors should prefer companies from customer goods sector which provide pharmacy or food. These shares outperform instruments issued by companies representing other sectors [Machmuddah et al., 2020]. In turn F. Stephany et al. propose the CoRisk-Index that enables to assess the industry-specific risk related to the pandemic crisis [Stephany et al., 2020].

\section{Methodology}

Using the Statistical Classification of Economic Activities in the European Community, we defined 11 economic sectors as order objects:

1) Agriculture, forestry and fishing;

2) Industry (except construction); 
3) Manufacturing;

4) Construction;

5) Wholesale and retail trade, transport, accommodation and food service activities;

6) Information and communication;

7) Financial and insurance activities;

8) Real estate activities;

9) Professional, scientific and technical activities; administrative and support service activities;

10) Public administration, defence, education, human health and social work activities;

11) Arts, entertainment and recreation; other service activities; activities of household and extra-territorial organizations and bodies.

The analysis of economic sectors during the pandemic was carried out on the basis of the evolution of the rate of return of 247 industry indices from 15 European countries in 2020 in line with the following list (the number of indices in the specific country was put in the brackets):

- Austria (10);

- Belgium (9);

- Denmark (19);

- Finland (28);

- France (9);

- Germany (16);

- Greece (13);

- Italy (23);

- Netherlands (9);

- Poland (16);

- Portugal (8);

- Russia (18);

- Sweden (22);

- Spain (18);

- United Kingdom (29).

All quotations of the indicators taking place in 2020 were assumed for the analysis. Depending on the index and stock exchange, the number of observations ranged from 250 to 258 quotes. For the calculation of the returns of both main national and sector indices, the historical nominal rates of return in 2020 were estimated. Moreover, the coefficients of variation of all the analyzed sectoral indices were calculated for the same observations.

The differences between the achieved rates of return on the industry and the main stock indices in all examined countries were calculated. In order to determine in more detail the behavior of individual sectoral indices, a study of selected economic sub-sectors was carried out:

1) Manufacturing:

- Industrials;

- Food \& Beverage;

- Textiles;

- Oil \& Gas; 
- Chemicals;

- Pharmaceuticals \& Biotechnology;

- Basic Materials;

- Automobiles \& Parts;

- Leisure Goods;

- Consumer Goods;

2) Information and Communication:

- Media;

- Telecommunications;

- Technology;

- Software \& Computer Services;

3) Financial and Insurance Activities:

- Banks;

- Insurance;

- Financials;

4) Arts, Entertainment and Recreation; other service activities; activities of household and extra-territorial organizations and bodies:

- Travel \& Leisure;

- Consumer Services.

In addition, an analysis of the differences in investor behavior between Russia and the other countries included in the study was carried out.

The statistical data was retrieved from "Investing.com"1.

\section{Results}

The estimation of the differences between the achieved rates of return on the industry indices and the rate of return of the main stock indices in each country covered by the research allowed to distinguish sectors that investors rated best and worst during the 2020 pandemic period. Investors' response to COVID-19 expressed by the difference between the annual nominal return of the main stock index and the sectoral index (in percent points) is presented below. There have been chosen sectors with the worst and the best rates of return:

A. The worst rates of return:

- Travel \& Leisure (-32.91);

- Oil \& Gas (-22.67);

- Banks (-15.55);

- Financial Services (-9.88);

- Consumer Services (-7.98).

B. The best rates of return:

- Leisure Goods (+63.64);

- Agriculture, Forestry \& Paper (+37.34);

- Technology (+30.76);

- Industrial Metals \& Mining (+28.25);

- Media (+20.15).

\footnotetext{
${ }^{1}$ URL: https://www.investing.com/ (accessed: 12.01.2021).
} 
In addition, the sectors with the highest and lowest volatility over the analysis period were identified (in percent points):

A. The highest volatility:

- Travel \& Leisure (23.54);

- Oil \& Gas (18.54);

- Banks (22.10);

- Leisure Goods (19.91);

- Automobiles \& Parts (16.34).

B. The lowest volatility:

- Health Care (8.14);

- Food \& Beverage (8.23);

- Pharmaceuticals \& Biotechnology (8.79);

- Telecommunications (8.80);

- Agriculture, Forestry \& Paper (10.02).

In general, the behavior of investors on the Russian market was similar to that of investors in other examined economies. However, for the three sub-sectors, the reaction of investors was different (Table 1).

Table 1. Observed difference in investors' response (Russia versus other countries)

\begin{tabular}{|l|l|c|}
\hline \multicolumn{2}{|c|}{ Country } & \multicolumn{2}{|c|}{ Index } & $\begin{array}{c}\text { Difference between the } \\
\text { annual nominal return of } \\
\text { the main stock index and } \\
\text { the sectoral index, }\end{array}$ \\
\hline \multicolumn{2}{|c|}{ Consumer Goods } \\
\hline Belgium & BEL Consumer Goods Net Return (BECG) & -13.25 \\
\hline Austria & ATX Consumer Products \& Services (ATXCPS) & 2.31 \\
\hline Finland & Helsinki Personal Goods (HX402040PI) & 14.39 \\
\hline Italy & FTSE Italia All Share Consumer Goods (FTIT3000) & 20.72 \\
\hline France & CAC Consumer Goods (FRCG) & 22.53 \\
\hline Spain & Madrid Consumer Goods (IBDC. MA) & 0.17 \\
\hline Netherlands & AEX Consumer Good (NLCG) & -15.33 \\
\hline Germany & DAX Consumer Goods (CXPYX) & -1.69 \\
\hline Portugal & PSI Consumer Goods Gross Return (PTCG) & -8.67 \\
\hline Russia & MOEX Consumer (MOEXCN) & 35.15 \\
\hline Russia & RTS Goods \& Retail (RTSCR) & 29.15 \\
\hline & \multicolumn{1}{|c|}{ Transport } & 3.20 \\
\hline Germany & DAX Transport i Logistic (CXPLX) & 5.92 \\
\hline Russia & MOEX Transport (MOEXTN) & -27.03 \\
\hline Finland & Helsinki Ind. Transportation (HX502060PI) & 27.07 \\
\hline Sweden & Stockholm Industrial Transportation PI (SX502060PI) & 2.51 \\
\hline Denmark & $\begin{array}{l}\text { OMX Copenhagen Industrial Transportation PI } \\
\text { (CX502060PI) }\end{array}$ & 1.44 \\
\hline United Kingdom & FTSE 350 Industrial Transportation (FTNMX2770) & \\
\hline & & \\
\hline
\end{tabular}




\begin{tabular}{|l|l|c|}
\hline \multicolumn{2}{|c|}{ Country } & \multicolumn{2}{c|}{ Financials } & $\begin{array}{c}\text { Difference between the } \\
\text { annual nominal return of } \\
\text { the main stock index and } \\
\text { the sectoral index, \% }\end{array}$ \\
\hline \multicolumn{2}{|c|}{ BEL Financials Net Return (BEFIN) } \\
\hline Belgium & ATX Financials (ATXFIN) & 0.04 \\
\hline Austria & Copenhagen Financials (CX30PI) & -8.85 \\
\hline Denmark & Helsinki Financials (HX30PI) & -33.22 \\
\hline Finland & CAC Financials (FRFIN) & -14.71 \\
\hline France & FTSE Financial Services (FTATFIN) & -13.34 \\
\hline United Kingdom & BCN Commerce \& Finance (ICOM.BC) & -11.62 \\
\hline Spain & Madrid Financial Services \& Real Estate (IFNC.MA) & -0.30 \\
\hline Spain & AEX Financials (NLFIN) & -10.91 \\
\hline Netherlands & DAX Financials (CXPVX) & -22.11 \\
\hline Germany & PSI Financials Gross Return (PTFIN) & 5.86 \\
\hline Portugal & MOEX Financials (MOEXFN) & -32.06 \\
\hline Russia & Stockholm Financials (SX30PI) & 13.38 \\
\hline Sweden & FTSE Italia All Share Financials (FTIT8000) & 1.90 \\
\hline Italy & FTSE 350 Financial Services (FTNMX8770) & -13.98 \\
\hline United Kingdom & 8.45 \\
\hline United Kingdom & FTSE 350 REITs (FTNMX8670) & -4.28 \\
\hline
\end{tabular}

\section{Discussion}

The economic downturn associated with the pandemic was unexpected. In many countries it led to the periodic closure or reduction of many industries due to the number of illnesses and deaths. This situation once again made it clear how strong the links among countries are and how robust due to the impact of demand and supply multipliers the interactions amid economic sectors are. The research confirms the relatively large dissonance between different sectors of the economy as a result of the varied impact of pandemic effects on their functioning (Table 2).

While the situation of many industries has been improved by the introduction of state support programs that mitigated the effects of the pandemic for companies, as well as the consequences of implementing a number of restrictions, this does not change the fact that business conditions have changed dramatically. Still, "uncertainty" is one of the most frequently mentioned words during a pandemic.

The results of the analysis confirm general trends in sector risks. The highest rates of return were obtained by the industries manufacturing products known as "Leisure Goods." The pandemic situation contributed to a lasting change in the way tourism, recreation, entertainment, culture, art, and other leisure activities are used. The need to maintain social distancing has forced changes to activities that were previously carried out in the traditional way. It is quite significant that the highest difference between the achieved sector and the main stock indices rates of return took place in the Nordic coun- 
Table 2. Industries mostly affected by negative consequences of COVID-19

\begin{tabular}{|l|l|l|}
\hline \multicolumn{1}{|c|}{ Sector } & Impact & \multicolumn{1}{|c|}{ Comment } \\
\hline Shopping malls & Negative & Lockdown \\
\hline $\begin{array}{l}\text { Entertainment (cinemas, theatres, museums, } \\
\text { etc.) }\end{array}$ & Negative & Lockdown + Social distance \\
\hline Passenger transport (train, airlines, coaches) & Negative & $\begin{array}{l}\text { Lockdown + Social distance + Movement } \\
\text { restrictions + Fear to be infected }\end{array}$ \\
\hline Hotels, Restaurants, Catering Cafe & Negative & $\begin{array}{l}\text { Lockdown + Social distance (limitations on } \\
\text { occupation) }\end{array}$ \\
\hline Travel agencies & Negative & $\begin{array}{l}\text { Movement restrictions + closure of hotels \& } \\
\text { resorts }\end{array}$ \\
\hline E-commerce & Positive & $\begin{array}{l}\text { Closing of shopping malls and traditional } \\
\text { shops + limited possibilities of using public } \\
\text { transport and leaving homes }\end{array}$ \\
\hline $\begin{array}{l}\text { Retail trade (food and articles of prime } \\
\text { necessity) }\end{array}$ & Positive & Closing of restaurants + fear of lockdown \\
\hline Pharmaceuticals and Health care & Positive & $\begin{array}{l}\text { Increased demand on medicines + additional } \\
\text { government funds spent on health care }\end{array}$ \\
\hline $\begin{array}{l}\text { Entertainment (gaming, TV productions, } \\
\text { etc.) }\end{array}$ & Positive & $\begin{array}{l}\text { Closing of cinemas and theatres + more time } \\
\text { spent at home }\end{array}$ \\
\hline Telecommunications & $\begin{array}{l}\text { Remote working + Remote education + } \\
\text { Development of e-commerce }\end{array}$ \\
\hline Logistics & Pevelopment of e-commerce \\
\hline
\end{tabular}

tries and concerned the following sector indices: Helsinki Leisure Goods (HX402030PI), Copenhagen Leisure Goods (CX402030PI), and Stockholm Leisure Goods (SX402030PI). High rates of return were for "Agriculture, Forestry \& Paper", "Technology," and "Industrial Metals \& Mining", mainly because these industries were not directly affected by the pandemic. Also, the position of "Media" is not surprising. Consumers sought to know as much as possible about the pandemic and how to protect against the disease, and found there information on the restrictions introduced. The fact that the Media sector flourishes is determined also by need to move the activity of companies, schools, and universities to the Internet, as well as the growth in satellite TV as an alternative for cinema or theatre. The weakest performance of the "Travel \& Leisure" is most influenced by the behavior of indices in three countries: FTSE Italia All Share Travel \& Leisure (FTIT5700), Copenhagen Travel \& Leisure (CX4050PI), and Helsinki Travel \& Leisure (HX4050PI). It should be noted that this sector is important for many European economies, both for the visitation of tourists and for countries where travel is a popular form of rest. The second place of the "Oil \& Gas" sector is mainly due to the negative trends taking place in the oil market. The reduction in population mobility, combined with the limitation of economic activity, has led to a decline in oil demand on an unprecedented scale. For instance oil production 
in Russia declined last year for the first time since 2008 and reached its lowest level since 2011 following a global deal to cut output and sluggish demand caused by the coronavirus. Russian oil and gas condensate output declined to 10.27 million barrels per day (bpd) last year ${ }^{2}$. The poor perception of the financial sectors is mainly due to the materialisation of credit risk: the deterioration of credit portfolios, the increase in the number of insolvent or illiquid borrowers, the increase in write-downs and provisions, which will consequently contribute to the loss of part of the income and profitability of banks. In addition, investors' perceptions of financial institutions were primarily influenced by central banks' actions to lower key interest rates. The "Consumer Services" sector is one of the most affected by the pandemic and the introduction of lockdowns. The effects of the collapse of the sector are particularly evident in large cities, where the number of people providing various types of services is relatively higher. Similar trends occur when analyzing sector volatility in 2020. The sectors most vulnerable to the effects of the pandemic were the most hesitant. On the other hand, the most stable sectors were "Health Care" and "Pharmaceuticals \& Biotechnology" and the "Telecommunication" sector.

For the Russian economy, dependent on raw material exports (which in 2019 accounted for $65 \%$ of the value of exports and $40 \%$ of budget revenues), the effects of the pandemic had to be felt - in April 2020 Russian exports diminished by $35 \%$ yoy. The decrease in demand for raw materials and the accompanying fall in global industrial product prices resulted in a decline of non-metallic mineral extraction ( $37 \%$ yoy), machine production ( $28 \%$ yoy), and light industry products (17\% yoy) in April and May 2020. Economic restrictions implemented in the fight against the COVID-19 pandemic also negatively affected the services sector, accounting for about $26 \%$ of Russian GDP - retail trade decreased by more than $21 \%$ yoy in April and May this year [Benedyczak, Zaniewicz, 2020].

The impact of the pandemic on the economies of the Russian Federation is in many ways similar to the impact that the COVID crisis has had on the economies of other countries. Although the scale of the lockdown in Russia was much smaller, the structural consequences of the pandemic were most negatively affected by such industries as oil \& gas, tourism, passenger rail and air transportation, hotel business, entertainment, and commercial real estate. At the same time, a number of industries not only maintained their volumes, but also increased them. This applies to non-ferrous metallurgy, agriculture, construction, and retail trade. The need to combat COVID-19 has increased investment in research and development of innovative products for the treatment and prevention of coronovirus. Several vaccines have been developed, tested, registered, and produced in Russia: "Sputnik V" from the Institute. Gamalea, "EpiVacCorona" from the Center of Virology, and "Vector" and "KoviVak" from the Chumakov Centre.

The observed difference in investor perception of the "Consumer Goods" sector, MOEX Consumer Index (MOEXCN) and RTS Goods \& Retail Index (RTSCR) - both of which have seen big increases in 2020 - is only seemingly surprising compared to other countries. Attention should be paid to the specificity of the Russian market and consumer preferences in this regard. It is also quite symptomatic that similar trends have also been noticeable in France and Italy, i.e. also in countries where the luxury goods market in

${ }^{2}$ Russia's annual oil production tumbles for first time in 12 years. (2020) BusinessToday.In, January. URL: https://www.businesstoday.in/markets/commodities/russia-annual-oil-production-tumbles-for-firsttime-in-12-years/story/426767.html (accessed: 05.04.2021). 
particular plays a major role. The poor performance of the MOEX Transport Index (MOEXTN) is mainly due to the design of this index, which comprises only four companies: Aeroflot, DVMP OAO, NKHP PAO and Novoross Sea Port. It should be noted that other airlines in Europe have received much higher public aid than in Russia. On the other hand, the MOEX Financials Index (MOEXFN) recorded a fairly unexpectedly good result, outperforming other indices analyzed in this sector. Most European indices in the "Banks" and "Financials" industries have seen declines. In fact, only Russia and Germany reported positive results. Russian Central Bank Governor Elvira Nabiullina on the $18^{\text {th }}$ of February 2021 said the peak of loan restructuring had passed and that the banking sector was ready to live without COVID-19 support from the regulator [Golubkova, Ostroukh, 2021].

\section{Conclusion}

An analysis of the rates of return on industry sub-indices against the main stock indices allows to draw the following conclusions.

1. Sector risk has become one of the key factors for stock market investors' decisions during the pandemic.

2. Sector risks were determined by an industry's resilience to the economic impact of the pandemic crisis.

3. Tourism, oil \& gas, and financial sector are among the industries that investors consider to be the most vulnerable to COVID-19. This attribution is due to the constraints on displacement and the need to maintain social distance, the expected and observed slowdown in the economy, and to treat the financial sector as an industry that will take on the effects of the crisis more than others.

4. The need to transfer business to the Internet and the accelerated, partly forced digital transformation are prerequisites for investors' decisions to increase the share of technology companies in their portfolios. On the other hand, growing uncertainty is impacting the performance of providers of food and other necessities. The growth in demand for the above mentioned goods was possible, inter alia, because the government's economic support programmes helped to keep unemployment at pre-pandemic levels. Due to the administrative constraints put on tourism and passenger transport activities, demand for leisure goods has increased rapidly, which has translated into results and quotations of the entities responsible for their production. The pandemic crisis, contrary to the symptoms observed in Q1 2020 and the expectations of analysts, did not adversely affect industrial production.

5. In general, the behavior of investors on the Russian market was similar to that of investors in other examined economies. However, for the three sub-sectors, the reaction of investors was different.

The proposed approach to the industry risk assessment, at least for a period of dynamic changes in the conditions describing the functioning of the economy in the pandemic era, seems to be a better solution than the fundamental analysis commonly used by financial institutions. The aforementioned approach is based mainly on historical data, often distorted by state support. Based on investor sentiment, the investors' response measure allows for flexible and rapid adaptation of industry policies and limits to the changing 
epidemiological and economic situation. The proposed tool and methodology also allow an analysis of the dynamics and trends of sectoral risks, as well as its links with variables describing the macroeconomic and epidemiological situation. Furthermore, the analysis of indices instead of individual companies in a given industry makes possible neutralisation of idiosyncratic risks that could dominate an entity's assessment. However, the study has some limitations. These include, first of all, relying solely on a sample of companies representing a given industry, which create the value of the industry sub-index. Typically, listed companies, especially those constituting indices, are in relatively better economic and financial condition. Another area that requires further in-depth research is the subject structure of investors in individual markets and the average free float of portfolios that make up industry indices. In the authors' view, this may be relevant to the evolution of industry sub-indices and the perception of sector risk.

\section{References}

Albuquerque R. A., Koskinen Y., Yang S., Zhang C. (2020) Resiliency of environmental and social stocks: An analysis of the exogenous COVID-19 market crash. The Review of Corporate Finance Studies, vol. 9, iss. 3, pp. 593-621. https://doi.org/10.1093/rcfs/cfaa011

Alfaro L., Chari A., Greenland A., Schott P. K. (2020) Aggregate and firm-level stock returns during pandemics, in real time. NBER, Working Papers, no. 26950, pp.1-31. URL: http://www.nber.org/papers/w26950 (accessed: 06.10.2020).

Babuna P., Yang X., Gyilbag A., Awudi D., Ngmenbelle D., Bian D. (2020) The Impact of COVID-19 on the Insurance Industry. International Journal of Environmental Research and Public Health, no 17 (5766), pp. 1-14. https://doi.org/10.3390/ijerph17165766

Bagchi B., Chatterjee S., Ghosh R., Dandapat D. (2020) "Impact of COVID-19 on Global Economy" in Bagchi B., Chatterjee S., Ghosh R., Dandapat D.Coronavirus Outbreak and the Great Lockdown. Springer, pp. 15-26. https://doi.org/10.1007/978-981-15-7782-6_3

Baker S. R., Bloom N., Davis S. J., Terry S. J. (2020) COVID-Induced Economic Uncertainty. NBER, Working Papers, no. 26983, pp.1-17.

Benedyczak J., Zaniewicz M. (2020) Gospodarka rosyjska w czasie COVID-19. Biuletyn PISM, no 159. URL: https://www.pism.pl/publikacje/Gospodarka_rosyjska_w_czasie_COVID19 (accessed 30.03.2021).

Boissay F., Rungcharoenkitkul P. (2020) Macroeconomic effects of Covid-19: an early review. BIS Bulletin, no. 7, pp. 1-9. URL: https://www.bis.org/publ/bisbull07.htm (accessed: 04.05.2020).

Chang Ch., McAleer M., Wong W.-K. (2020) Risk and Financial Management of COVID-19 in Business, Economics and Finance. Journal of Risk and Financial Management, vol. 13, no. 5 (102), pp.1-7. https://doi.org/10.3390/jrfm13050102

Coibion O., Gorodnichenko Y., Weber M. (2020) Labor markets during the covid-19 crisis: A preliminary view. NBER Working Papers, no. 27017, pp. 1-15. https://doi.org/10.3386/w27017

Czech K., Wielechowski M. (2021) Is the Alternative Energy Sector COVID-19 Resistant? Comparison with the Conventional Energy Sector: Markov-Switching Model Analysis of Stock Market Indices of Energy Companies. Energies, vol. 14, no. 4 (988), pp. 1-17. https://doi.org/10.3390/en14040988

Demirguc-Kunt A., Pedraza A., Ruiz C. (2020) Banking sector performance during the COVID-19 Crisis. World Bank, Policy Research Working Paper Series, no. 9363, pp.1-55. URL: https://openknowledge. worldbank.org/handle/10986/34369 (accessed: 28.09.2020).

Dhall R., Singh B. (2020) The COVID-19 Pandemic and Herding Behaviour: Evidence from India's Stock Market. Millennial Asia, vol. 11, iss. 3, pp. 366-390. https://doi.org/10.1177/0976399620964635

Ding W., Levine R., Lin Ch., Xie W. (2020) Corporate immunity to the COVID-19 pandemic. NBER, Working Paper, no. 27055, pp. 1-54. URL: http://www.nber.org/papers/w27055 (accessed: 07.02.2021).

Espejo W., Celis J.E., Chiang G., Bahamonde P. (2020) Environment and COVID-19: Pollutants, impacts, dissemination, management and recommendations for facing future epidemic threats. Science of The Total Environment, vol. 747, no. 141314. https://doi.org/10.1016/j.scitotenv.2020.141314

Gamil Y., Alhagar A. (2020) The Impact of Pandemic Crisis on the Survival of Construction Industry: A Case of COVID-19. Mediterranean Journal of Social Sciences, no. 11, pp. 2039-2117. https://doi. org/10.36941/mjss-2020-0047 
Gerding F., Martin, T., Nagler F. (2020) Sovereign Debt and Equity Returns in the Face of Disaster, pp. 1-48. https://doi.org/10.2139/ssrn.3572839

Gherghina Ș.C., Armeanu D.Ș., Joldeș C.C. (2020) Stock Market Reactions to COVID-19 Pandemic Outbreak: Quantitative Evidence from ARDL Bounds Tests and Granger Causality Analysis. International Journal of Environmental Research and Public Health, vol. 17, no. 18 (6729), pp.1-35. https://doi.org/10.3390/ijerph17186729

Golubkova K., Ostroukh A. (2021) Russian banking sector ready to live without COVID-19 support. Reuters, February 18. URL: https://www.reuters.com/article/russia-cenbank-banks-idUSL8N2KO32D (accessed: 05.04.2021).

Gormsen N. J., Koijen R. S. J. (2020) Coronavirus: Impact on stock prices and growth expectations. Working Paper, University of Chicago, Becker Friedman Institute of Economics, no. 2020-22, pp. 1-34. https:// doi.org/10.2139/ssrn.3555917

Guttmann R., Lawson D., Rickards P. (2020) The Economic Effects of Low Interest Rates and Unconventional Monetary Policy. Reserve Bank of Australia, pp.1-10. URL: https:/www.rba.gov.au/publications/ bulletin/2020/sep/the-economic-effects-of-low-interest-rates-and-unconventional-monetary-policy. html (accessed: 21.03.2021).

Hassan T. A., Hollander S., van Lent L., Tahoun A. (2020) Firm-level exposure to epidemic diseases: COVID-19, SARS, and H1N1. Working Paper, Institute for New Economic Thinking, no. 119, pp. 1-46. https://doi.org/10.36687/inetwp119

Hutchinson J., Mee S. (2020) The impact of the ECB's monetary policy measures taken in response to the COVID-19 crisis. ECB, Economic Bulletin, no 5/2020. URL: https://www.ecb.europa.eu/pub/ economic-bulletin/focus/2020/html/ecb.ebbox202005_03 12b5ff68bf.en.html (accessed: 23.02.2021).

Jean S. (2020) How the COVID-19 Pandemic Is Reshaping the Trade Landscape and What to Do About It. Intereconomics, 55 (3), pp.135-139. URL: https://www.intereconomics.eu/contents/year/2020/ number/3/article/how-the-covid-19-pandemic-is-reshaping-the-trade-landscape-and-what-to-doabout-it.html (accessed: 19.06.2021).

Kohlscheen E., Mojon B., Rees D. (2020) The macroeconomic spillover effects of the pandemic on the global economy. BIS, Bulletin no. 4, pp. 1-9. URL: https://www.bis.org/publ/bisbull04.htm (accessed: 02.12.2020).

Korzeb Z., Niedziółka P., Silva A. (2021a) Impact of the COVID-19 crisis on the Portuguese banking system. Linear ordering method. Estudios Gerenciales, vol. 37, no. 159, pp. 226-241. https://doi.org/10.18046/j. estger.2021.159.4414

Korzeb Z., Niedziółka P. (2021b) Determinants of Differentiation of Cost of Risk (CoR) among Polish Banks during COVID-19 Pandemic. Journal of Risk and Financial Management, vol. 14, no. 3 (110). https:// doi.org/10.3390/jrfm14030110

Korzeb Z., Niedziółka P. (2020) Resistance of commercial banks to the crisis caused by the COVID-19 pandemic: the case of Poland. Equilibrium. Quarterly Journal of Economics and Economic Policy, vol. 15, iss. 2, pp. 205-234. https://doi.org/10.24136/eq.2020.010

Kulińska-Sadłocha E., Marcinkowska M., Szambelańczyk J. (2020) The impact of pandemic risk on the activity of banks based on the Polish banking sector in the face of COVID-19. Safe Bank, no. 2, pp.3159. https://doi.org/https://0.26354/bb.3.2.79.2020

Landier A., Thesmar D. (2020). Earnings expectations in the covid crisis. NBER, Working Papers, no. 27160, pp. 1-26. URL: http://www.nber.org/papers/w27160.pdf (accessed: 11.12.2020).

Machmuddah Z., Utomo S.D., Suhartono E., Ali S., Ali Ghulam W. (2020) Stock Market Reaction to COVID-19: Evidence in Customer Goods Sector with the Implication for Open Innovation. Journal of Open Innovation: Technology, Market, and Complexity, vol. 6, no. 4 (99). https://doi.org/10.3390/ joitmc6040099

Monteiro A., Eusébio C., Carneiro M.J., Madaleno M., Robaina M., Rodrigues V., Gama C., Relvas H., Russo M., Oliveira K., Lopes M., Borrego C. (2021) Tourism and Air Quality during COVID-19 Pandemic: Lessons for the Future. Sustainability, vol. 13, no. 7 (3906), pp.1-22. https://doi.org/10.3390/ sul3073906

Orhan Z.H., Tirman N. (2020) Analysis of the Impact of Covid-19 on Different Sectors in Turkey During Early Periods of the Pandemic. Journal of Business Research - Turk, no. 12, pp. 2312-2326. https://doi. org/10.20491/isarder.2020.978

Pagano M., Wagner Ch., Zechner J. (2020) Disaster Resilience and Asset Prices. CSEF, Working Papers, no. 563, pp. 1-45. URL: https://www.csef.it/WP/wp563.pdf (accessed: 02.04.2021). 
Papadimitriou E., Cseres-Gergelyne Blaskó Z. (2020) Economic sectors at risk due to COVID-19 disruptions: will men and women in the EU be affected similarly. Publications Office of the European Union, pp. 1-21. https://doi.org/10.2760/50058

Salisu A. A., Ogbonna A. E., Oloko T. F., Adediran I. A. (2021) A New Index for Measuring Uncertainty Due to the COVID-19 Pandemic. Sustainability, vol. 13, no. 6 (3212), pp.1-18. https://doi.org/10.3390/ su13063212

Sansa N. The impact of the corona virus on the financial market: Evidence from China and U.S.A. (2020) Electronic Research Journal of Social Sciences and Humanities, vol. 2, iss. 2, pp.1-11. https://doi. org/10.2139/ssrn.3567901

Stephany F., Stoehr N., Darius P., Neuhäuser L., Teutloff O., Braesemann F. (2020) Which industries are most severely affected by the COVID-19 pandemic? A data-mining approach to identify industry-specific risks in real-time. Working Paper. URL: https://www.researchgate.net/profile/ Philipp-Darius/publication/340271096_Which_industries_are_most_severely_affected_by_the_ COVID-19_pandemic_A_data-mining_approach_to_identify_industry-specific_risks_in_real-time/ links/5e988938299bf13079a1a347/Which-industries-are-most-severely-affected-by-the-COVID-19pandemic-A-data-mining-approach-to-identify-industry-specific-risks-in-real-time.pdf (accessed: 14.03.2021).

Tsenzharik M., Krylova Y., Steshenko V. (2020) Digital transformation in companies: Strategic analysis, drivers and models. St Petersburg University Journal of Economic Studies, vol. 36, no. 3, pp.390-420. https://doi.org/10.21638/spbu05.2020.303 (In Russian)

Valls Martínez M.d. C., Martín Cervantes P.A. (2021) Testing the Resilience of CSR Stocks during the COVID-19 Crisis: A Transcontinental Analysis. Mathematics, vol. 9, no. 5, (514), pp. 1-24. https://doi. org/10.3390/math9050514

Zhang D., Hu M., Ji Q. (2020) Financial markets under the global pandemic of COVID-19. Finance Research Letters, vol. 36, pp. 1-6. https://doi.org/10.1016/j.frl.2020.101528

Received: 12.04 .2021

Accepted: 30.06.2021

Authors'information:

Zbigniew Korzeb - Dr. Sci. in Economics, Professor; z.korzeb@pb.edu.pl

Paweł Niedziółka - Dr. Sci. in Economics, Professor; pniedz@sgh.waw.pl

Dzmitry A.Pankou — Dr. Sci. in Economics, Professor; pankov_d@bseu.by

\section{Оценка чувствительности рынков капитала к развитию пандемии COVID-19}

\section{3. Корзеб ${ }^{1}$, П. Недзиолка ${ }^{2}$, Д. А. Панков ${ }^{3}$}

${ }^{1}$ Белостокский технический университет,

Республика Польша, 16-001, Клеосин, ул. О. Стефана Тарасюка, 2

2 Варшавская школа экономики, Республика Польша, 02-554, Варшава, ал. Независимости, 162

${ }^{3}$ Белорусский государственный экономический университет, Республика Беларусь, 220070, Минск, пр. Партизанский, 26

Для цитирования: Korzeb Z., Niedziołka P., Pankou D. A. (2021) Capital markets and perceptions of sectoral sensitivity to COVID-19. Вестник Санкт-Петербургского университета. Экономика. T.37. Вып. 3. С. 474-488. https://doi.org/10.21638/spbu05.2021.305

Авторами статьи проведен анализ показателей отраслевых субиндексов на обозримом отрезке времени пандемии COVID-19, реализованный на основе оценки динамики норм доходности 247 отраслевых индексов из 15 европейских стран в 2020 г. Исследованы различия между достигнутыми нормами доходности промышленности и основными фондовыми индексами во всех исследуемых странах. Кроме того, была рассчитана волатильность отдельных отраслевых индексов. Результаты проведенного исследо- 
вания позволяют сделать следующие выводы. Во-первых, туризм, нефтегазовый и финансовый сектор относятся к числу отраслей, которые инвесторы считают наиболее уязвимыми для COVID-19. Во-вторых, необходимость перевода бизнеса в Интернет, а также ускорение (отчасти вынужденное) цифровой трансформации бизнеса являются предпосылками для принятия инвесторами решений об увеличении доли технологических компаний в своих портфелях. С другой стороны, растущая неопределенность влияет на работу поставщиков продовольствия и других предметов первой необходимости. Из-за административных ограничений, наложенных на туристическую и пассажирскую транспортную деятельность, спрос на товары для отдыха быстро возрос, что отразилось на результатах и котировках предприятий, ответственных за их производство. Пандемический кризис, вопреки наблюдавшимся в 1-м квартале 2020 г. симптомам и ожиданиям аналитиков, не оказал негативного влияния на промышленное производство. В-третьих, в целом поведение инвесторов на российском рынке было аналогично поведению инвесторов в других исследуемых экономиках. Однако по трем подсекторам экономики реакция инвесторов была разной.

Ключевые слова: COVID-19, рынки капитала, секторный риск.

Статья поступила в редакцию: 12.04.2021

Статья рекомендована в печать: 30.06.2021

Контактная информация:

Корзеб Збигнев - д-р экон. наук, проф.; korzeb@pb.edu.pl

Недзиолка Павел - д-р экон. наук, проф.; pniedz@sgh.waw.pl

Панков Дмитрий Алексеевич - д-р экон. наук, проф.; pankov_d@bseu.by 